\title{
Pengaruh Sistem Informasi Akuntansi (SIA) Terhadap Efektifitas Pelaporan Akuntansi UMKM di Desa Banyuanyar
}

\author{
Eni Srihastuti \\ Universitas Islam Kadiri \\ Email: enisrihastuti@uniska-kediri.ac.id \\ Imarotus Suaidah \\ Universitas Islam Kadiri \\ Email:Imarotus@uniska-kediri.ac.id \\ Siti Isnaniati \\ Universitas Islam Kadiri \\ Email: sitiisnaniati@uniska-kediri.ac.id
}

\begin{abstract}
This study aims to determine how the effect of accounting information systems on the effectiveness of MSME accounting reporting in Banyuanyar village. This research uses descriptive quantitative method to describe the condition of the research object in accordance with the reality. The sampling technique used was incidental sampling, using test instruments including validity and reliability tests. Meanwhile, the data analysis used in this research includes classical assumption test, simple regression analysis, coefficient of determination, and hypothesis testing. Based on the results of the analysis of the validity test and reliability test, it can be seen that all data are valid. All question items for the two variables the significance value is less than the specified significance value. The data are reliable from the Cronbach's alpha test $>0.60$. Meanwhile, for the regression test, it is known that the regression line is $\mathrm{Y}=39.396+0.026 \mathrm{X}$. From the results of the simple regression test conducted, it was found that the application (AIS) of the accounting information system had no effect on the effectiveness of the financial statements received. This can be seen from the t test significance value of $0.656>$ 0.05. The acceptance of the null hypothesis is due to many factors, including a lack of understanding of the importance of accounting information systems and financial reporting.
\end{abstract}

Keywords: Accounting Information Systems, Financial Statements, SMEs

\begin{abstract}
Abstrak
Penelitian ini bertujuan untuk mengetahui bagaimana pengaruh sistem informasi akuntansi terhadap efektifitas pelaporan akuntansi UMKM di desa Banyuanyar. Penelitian ini menggunakan metode deskriptif kuantitatif untuk menggambarkan kondisi objek penelitian sesuai dengan realitanya. Teknik sampling yang dipakai adalah sampling insidental, menggunakan uji instrumen meliputi uji validitas dan reliabilitas. Sedangkan analisis data yang digunakan dalam penelitian meliputi uji asumsi klasik, analisis regresi sederhana, koefisien determinasi, dan uji hipotesis. Berdasarkan hasil analisis uji validitas dan uji reliabilitas, dapat diketahui semua data bersifat valid. Semua item pertanyaan untuk kedua variabel nilai signifikansinya kurang dari nilai signifikansi yang ditentukan. Data bersifat reliabel dari uji cronbach's alpha $>0.60$. Sedangkan untuk pengujian regresinya diketahui garis regresinya $\mathrm{Y}=39.396+0.026 \mathrm{X}$. Dari hasil uji regresi sederhana yang dilakukan, didapatkan bahwa pengaplikasian (SIA) sistem informasi akuntansi tidak mempunyai pengaruh terhadap efektifitas laporan keuangan diterima. Ini dapat dilihat dari nilai signifikansi uji t sebesar 0,656>0,05. Penerimaan hipotesis nol dikarenakan banyak faktor, diantaranya adalah kurangnya pemahaman tentang arti penting sistem informasi akuntansi dan pelaporan keuangan.
\end{abstract}

Kata kunci: Sistem Informasi Akuntansi, Laporan Keuangan, UMKM

\section{Pendahuluan}

Sistem Informasi Akuntansi (SIA) adalah sebuah sistem informasi yang mengubah data dari transaksi - transaksi bisnis, menjadi data yang berguna/bermanfaat bagi pemakainya (Kusrini, 2010: 10). SIA berguna sebagai acuan dalam pengambilan keputusan bisnis. Dengan adanya SIA pedagang atau 
pebisnis dapat menentukan keuntungan dalam satu periode, jumlah kekayaan yang dimiliki, dan jumlah tanggungan yang harus dimiliki. Selain itu, juga dapat digunakan untuk mengetahui aliran masuk dan keluar dana. Dengan demikian pebisnis atau pedagang dapat dengan mudah mengetahui laba rugi. Kemudian dari data-data akuntansi tersebut mereka dapat merencanakan langkah apa yang seharusnya diambil untuk memaksimalkan bisnis yang digeluti.

Berbicara mengenai bisnis atau usaha, maka yang menjadi titik awal adalah UMKM (Usaha Mikro Kecil Menengah). UMKM sendiri merupakan usaha / bisnis yang dikelola perorangan atau kelompok yang mempunyai modal kurang dari Rp 200.000.000,00. Contoh UMKM di antaranya pedagang sayur, penjual nasi, counter, warnet, dan lain-lain.

Berdasarkan penelitian yang dilakukan Pinasti (2007), Sebagian pengusaha kecil yang ada di Indonesia tidak menggunakan informasi akuntansi(SIA) dalam mengelola bisnis atau usahanya. Pada penelitian ini peneliti mengambil data dari Desa Banyuanyar yang mayoritas penduduknya petani dan pedagang. Pinasti (2007) menjelaskan bawasannya para pengusaha kecil belum mempunyai pengetahuan tentang akuntansi. Hal ini disebabkan oleh persepsi pengusaha kecil bahwa pencatatan atau akuntansi tidak penting, rumit, dan hanya menambah pekerjaan.

Sebagai catatan bahwa UMKM merupakan tonggak penyokong perekonomian suatu bangsa. Sehingga sangat penting untuk meningkatkan keuntungan tiap UMKM. Pada penelitian ini, penulis ingin mengetahui bagaimana pengaruh dari penerapan sistem informasi akuntansi (SIA) terhadap efektifitas pelaporan keuangan UMKM di Desa Banyuanyar. Selain itu, peneliti juga ingin mengetahui informasi tentang pendapat para pedagang di Desa Banyuanyar tidak menggunakan SIA.

\section{Kajian Pustaka}

2.1 Sistem Informasi

Sistem informasi ialah suatu sistem yang mengelola kegiatan harian pada organisasi, mendukung jalannya operasi, mempunyai sifat manajerial, dan menyediakan informasi bagi pihak-pihak tertentu dengan laporan-laporan yang dibutuhkan (Hutahaean, 2014:13). Sedangkan menurut Anggraeni \& Irviani (2017) menerangkan sistem informasi sebagai suatu gabungan yang teratur dari hardware, software, orang-orang, jaringan komunikasi dan sumber daya data untuk mengumpulkan, mengubah, lalu menyebarkan informasi dalam suatu organisasi. Jadi secara sederhana dapat disimpulkan bahwa sistem informasi merupakan kumpulan komponen pembentuk informasi (data, perangkat keras, perangkat lunak, orang, serta jaringan komunikasi) yang saling berkorelasi dan tersusun dengan teratur.

Menurut (Mulyani \& dkk, 2018) sistem informasi terdiri atas enam komponen seperti perangkat lunak, perangkat keras, prosedur (methode), sumber daya manusia (human resource), basis data, komunikasi data dan jaringan komputer :

a. Perangkat keras (hardware), terdiri dari piranti-piranti fisik seperti komputer, CPU, laptop, printer, dll.

b. Perangkat lunak (software), yang terdiri dari sekumpulan instruksi untuk mengoperasikan (hardware) perangkat keras.

c. Prosedur, merupakan sekumpulan aturan yang digunakan untuk pemrosesan data.

d. Sumber daya manusia, dimana pihak - pihak yang bertanggung jawab dalam pemrosesan sistem informasi.

e. Basis data (database), tempat menyimpan kumpulan data. 
Gambar 1. Komponen Sistem Informasi

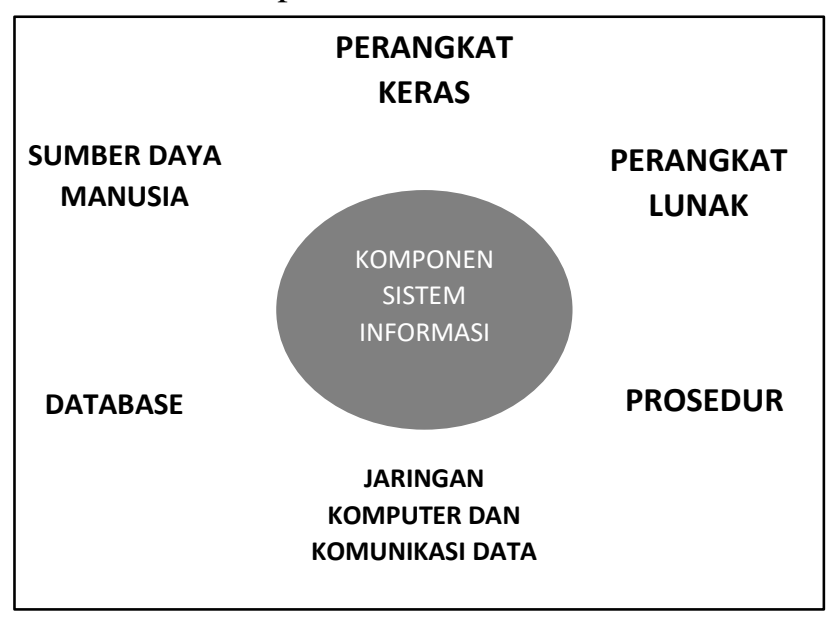

Sumber: (Mulyani \& dkk, 2018)

\section{$2.2 \quad$ Sistem Informasi Akuntansi}

Sistem informasi akuntansi (SIA) merupakan sekumpulan komponen informasi yang digunakan dalam kegiatan akuntansi. Adanya sistem informasi akuntansi memungkinkan terciptanya keteraturan dalam intern organisasi. Hal ini dikarenakan SIA mempermudah sumber daya manusia (SDM) dalam memperoleh informasi terkait ekonomi organisasi. Informasi ini dimanfaatkan dalam proses pengambilan dan penentuan keputusan.

Sistem informasi akuntansi (SIA) juga memiliki komponen penyusun. Komponen tersebut sama dengan komponen yang dimiliki sistem informasi yaitu, software, hardware, prosedur, sumber daya manusia, dan basis data. Mahatmayo (2014:5) menjelaskan komponen-komponen yang memungkinkan sistem informasi akuntansi memiliki fungsi-fungsi penting diantaranya adalah mengumpulkan serta menyimpan data mengenai kegiatan - kegiatan yang dilaksanakan, agar pihak manajemen, para pegawai, dan pihak eksternal/pihak luar yang berkepentingan dapat meninjau/mengkaji ulang hal-hal yang telah terjadi dalam organisasi.

Mengubah data-data menjadi informasi yang berguna bagi manajemen dalam membuat keputusan dalam aktivitas perencanaan, pelaksanaan, dan pengawasan. Menyediakan pengendalian yang memadai untuk menjaga aset organisasi termasuk data-data organisasi, dan juga untuk memastikan data-data tersebut tersedia saat dibutuhkan secara akurat, dan andal.

\section{Metode Penelitian}

Penelitian ini menggunakan metode penelitian kuantitatif survey dengan tingkat eksplanasi asosiatif kausal. Merupakan penelitian yang bertujuan untuk menganalisis hipotesis dan mengetahui pengaruh atau hubungan antara variabel bebas terhadap variabel terikat (Aliya \& Tobari, 2019).

Populasi penelitian adalah seluruh pelaku UMKM di Desa Banyuanyar Kecamatan. Gurah yang berjumlah 126 orang. Adapun sampel pada penelitian berjumlah 50 responden yang diambil secara insidental, yaitu siapa saja yang secara kebetulan bertemu dengan peneliti dapat digunakan sebagai sampel, bila dipandang yang ditemui itu cocok sebagai sumber data.

Pengumpulan data secara langsung melalui pengelolaan kuesioner yang telah valid melalui uji validitas dan reliabilitas. Skala pengukuran menggunakan skala likert. Melakukan analisis regresi linear 
sederhana untuk menguji dampak pengaruh Sistem Informasi Akuntansi (SIA) Terhadap Efektifitas Pelaporan Akuntansi UMKM.

Adapun operasional variabel penelitian yang digunakan sebagai berikut.

Tabel 1. Operasional Variabel (SIA) Sistem Informasi Akuntansi, Efektifitas Laporan Keuangan UMKM di Desa Banyuanyar

\begin{tabular}{|l|rl|}
\hline \multicolumn{1}{|c|}{ Variabel } & \multicolumn{1}{c|}{ Dimensi } \\
\hline $\begin{array}{l}\text { Variabel Independen Sistem Informasi } \\
\text { Akuntansi UMKM di Desa Banyuanyar (X) }\end{array}$ & 1. Sistem Informasi (SIA) kas \\
\hline & 2. & Sistem Informasi (SIA) persediaan \\
\hline & 3. & Sistem Informasi (SIA) Piutang \\
\hline & 4. & Sistem Informasi (SIA) utang \\
\hline $\begin{array}{l}\text { Variabel Dependen Efektifitas Laporan } \\
\text { Keuangan UMKM di Desa Banyuanyar (Y) }\end{array}$ & 1. & $\begin{array}{l}\text { Kistem Informasi (SIA) pokok } \\
\text { ukuran efektifitas laporan keuangan. }\end{array}$ \\
\hline & 2. $\begin{array}{l}\text { Standar akuntansi sebagai pedoman } \\
\text { efektifitas laporan keuangan }\end{array}$ \\
\hline
\end{tabular}

Sumber: Data Diolah, 2020

Setelah diperoleh data, dilakukan analisis data meliputi : uji validitas lalu uji reliabilitas dilanjutkan asumsi klasik terakhir uji hipotesis.

\section{Hasil dan Pembahasan}

Untuk menjawab semua pertanyaan pada rumusan masalah, maka dilakukan serangkaian analisa data yang meliputi: analisa validitas, reliabilitas. Pengujian asumsi klasik : normalitas, heteroskedastisitas, auto korelasi. Dilanjutkan pengujian hipotesis meliputi uji regresi, uji t serta uji determinasi. Hasil pengujian dapat dipaparkan sebagai berikut:

1) Validitas. Semua data bersifat valid karena hasil uji korelasi PPM nya menunjukkan bahwa nilai signifikan semua pertanyaan sistem informasi akuntansi(SIA) kurang dari 0,05. Ringkasan seperti terlihat berikut ini:

Tabel 2. UjiValiditas SIA(SistemInformasiAkuntansi)

\begin{tabular}{|r|r|r|l|l|}
\hline \multicolumn{1}{|l|}{$\begin{array}{l}\text { Var. } \\
\text { SIA }\end{array}$} & r- hit & r- tab $(0.05)$ & sig & Ket \\
\hline P1 & $.756^{* *}$ & .279 & .000 & VALID \\
\hline P2 & $.710^{* *}$ & .279 & .000 & VALID \\
\hline P3 & $.565^{* *}$ & .279 & .000 & VALID \\
\hline P4 & $.328^{*}$ & .279 & .020 & VALID \\
\hline P5 & $.756^{* *}$ & .279 & .000 & VALID \\
\hline P6 & $.316^{*}$ & .279 & .025 & VALID \\
\hline P7 & $.441^{* *}$ & .279 & .001 & VALID \\
\hline P8 & $.756^{* *}$ & .279 & .000 & VALID \\
\hline P9 & $.710^{* *}$ & .279 & .000 & VALID \\
\hline P10 & $.756^{* *}$ & .279 & .000 & VALID \\
\hline P11 & $.441^{* *}$ & .279 & .001 & VALID \\
\hline
\end{tabular}




\begin{tabular}{|l|l|l|l|l|}
$\mathrm{P} 12$ & $.565 * *$ & .279 & .000 & VALID \\
\hline $\mathrm{P} 13$ & $.710^{* *}$ & .279 & .000 & VALID \\
\hline $\mathrm{P} 14$ & $.565 * *$ & .279 & .000 & VALID \\
\hline $\mathrm{P} 15$ & $.441 * *$ & .279 & .001 & VALID \\
\hline $\mathrm{P} 16$ & $.441 * *$ & .279 & .001 & VALID \\
\hline $\mathrm{P} 17$ & $.565 * *$ & .279 & .000 & VALID \\
\hline
\end{tabular}

Sumber: Data Diolah, 2020

Sedangkan untuk efektifitas laporan keuangan nya terlihat berikut:

Tabel 3. Uji Validitas Efektifitas Laporan Keuangan

\begin{tabular}{|r|r|r|r|r|}
\hline $\begin{array}{c}\text { Var } \\
\text { Y }\end{array}$ & r hitg & r tab (0.05) & Sig & Ket \\
\hline P1 & $.603^{* *}$ & .279 & .000 & VALID \\
\hline P2 & $.437^{* *}$ & .279 & .001 & VALID \\
\hline P3 & $.609^{* *}$ & .279 & .000 & VALID \\
\hline P4 & $.350^{*}$ & .279 & .013 & VALID \\
\hline P5 & $.609^{* *}$ & .279 & .000 & VALID \\
\hline P6 & $.437^{* *}$ & .279 & .001 & VALID \\
\hline P7 & .242 & .279 & .001 & VALID \\
\hline P8 & $.609^{* *}$ & .279 & .000 & VALID \\
\hline P9 & $.603^{* *}$ & .279 & .000 & VALID \\
\hline P10 & $.473^{* *}$ & .279 & .001 & VALID \\
\hline
\end{tabular}

Sumber: Data Diolah, 2020

2) Uji Reliabilitas

Bila nilai koefisien alpha cronbach's nya > 0.60 maka data yang diujikan dinyatakan reliabel.

Tabel 4. Uji Reliabilitas Sistem Informasi Akuntansi dan Efektifitas Laporan Keuangan

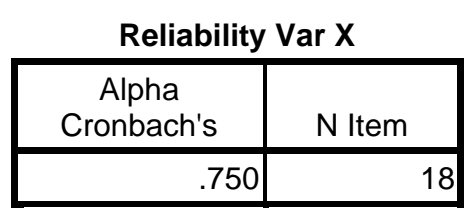

Reliability Var Y

\begin{tabular}{|r|r|}
\hline $\begin{array}{c}\text { Alpha } \\
\text { Cronbach's }\end{array}$ & N Item \\
\hline .704 & 11 \\
\hline
\end{tabular}

Sumber: Data Diolah, 2020

Tabel diatas menunjukkan bahwa, variabel $\mathrm{X}$ dan $\mathrm{Y}$ dikatakan reliabel. Hal ini karena nilai koefisien alpha cronbach's nya masing masing 0.750 dan 0.704 yang berarti ada diatas kriteria yang ditentukan. 
3) Uji asumsi klasik yang dilakukan terdiri dari uji:

a. Tes Normalitas data. Berdasar hasil pengujian data diketahui :

Tabel 5. Hasil Uji Normalitas dari Sistem Informasi Akuntansi dan Efektifitas Laporan keuangan

Tes Kolmogorov-Smirnov
\begin{tabular}{|lc|r|r|}
\hline \multicolumn{1}{|c|}{} & \multicolumn{1}{c|}{$\mathrm{X}$} & \multicolumn{1}{c|}{$\mathrm{Y}$} \\
\hline $\mathrm{N}$ & 50 & 50 \\
Normal & Mean & 65.2600 & 41.1200 \\
Parameter & Std. Deviasi & 5.92404 & 2.42133 \\
Kolmogorov - Smirnov Z & .788 & 1.133 \\
\multicolumn{2}{|l|}{ Asymp. Sig. (2-tailed) } & .564 & .153 \\
\hline
\end{tabular}

Sumber: Data Diolah, 2020

Tabel 5 diatas, menjelaskan bahwa data bersifat normal, berdasarkan nilai asymp.sig yang lebih besar dari 0,05 .

b. Uji Heteroskedastisitas.

Gambar 1. Hasil Uji Heteroskedastisitas Sistem Informasi Akuntansi dan Efektifitas Laporan Keuangan

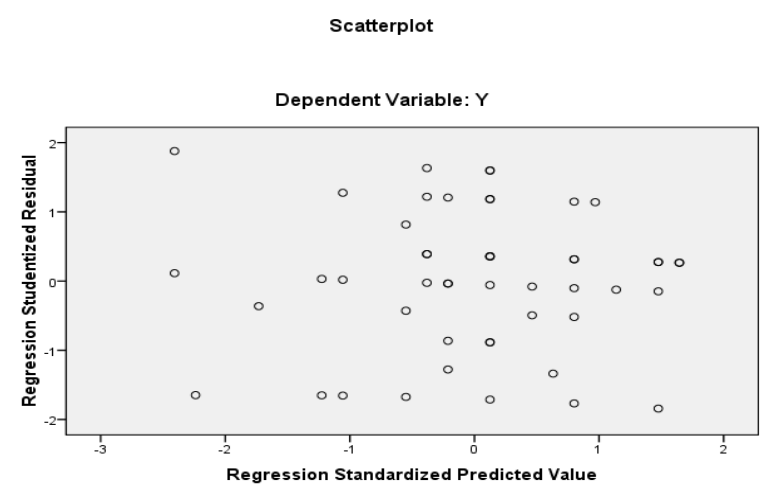

Sumber: Data Diolah, 2020

Berdasarkan gambar diatas terlihat bahwa titik titiknya menyebar, hal ini mengindikasikan bahwa data bersifat homoskedastisitas atau tidak bersifat heterokedastisitas.

c. Uji Autokorelasi.

Tabel 6. Uji Autokorelasi Sistem Informasi Akuntansi dan Efektifitas Laporan keuangan

Model Summaryb

\begin{tabular}{|l|r|r|r|r|r|}
\hline Model & \multicolumn{1}{|c|}{$\mathrm{R}$} & \multicolumn{1}{c|}{$\mathrm{R}^{2}$} & \multicolumn{1}{c|}{ Adj $\mathrm{R}^{2}$} & Estimasi Std. Error & Durbin-Watson \\
\hline 1 & $.065^{\mathrm{a}}$ & .004 & -.017 & 2.44131 & 1.498 \\
\hline
\end{tabular}

Sumber: Data Diolah, 2020 
Berdasarkan kriteria bila nilai uji Durbin-Watson antara -2 sampai +2 , maka data dikatakan bebas dari otokorelasi. Tabel di atas menjelaskan bahwa nilai Uji Durbin-Watson sebesar 1.498. Berarti nilainya berada diantara -2 dengan +2 yang artinya data bebas dari auto korelasi.

\section{4) Uji Hipotesis.}

Dalam pengujian hipotesis dimulai dari uji regresi yang meliputi uji t dan uji koefisien determinasi. Tahapan analisa data selengkapnya dapat dijelaskan sebagai berikut:

\section{a. Uji Regresi}

Tabel 7. Uji Regresi

\begin{tabular}{|r|r|r|r|r|}
\hline \multirow{2}{*}{ Model } & \multicolumn{2}{|c|}{ Koefisien Unstandaris } & \multicolumn{1}{c|}{$\mathrm{t}$} & \multicolumn{1}{c|}{ Sig. } \\
\cline { 2 - 5 } & $\mathrm{B}$ & Std. Error & & \\
\hline $1 \quad$ (Constant) & 39.396 & 3.857 & 10.213 & .000 \\
$\mathrm{X}$ & .026 & .059 & .449 & .656 \\
\hline
\end{tabular}

Sumber: Data Diolah, 2020

Berdasarkan tabel diatas dapat dibuat garis model regresinya, $\mathrm{Y}=39.396+0.026 \mathrm{X}$. Dari tabel untuk uji regresi terlihat nilai signifikansi untuk sistem informasi akuntansi yaitu 0.656. Nilai signifikansi dari hasil uji regresi lebih besar dari 0,05. Ini artinya, bahwa sistem informasi akuntansi (SIA) berpengaruh kepada efektifitas laporan keuangan tetapi tidak signifikan, atau dengan kata lain, hasil analisa yang diperoleh dari sampel tidak dapat diberlakukan kepada populasi UMKM studi kasus di Desa Banyuanyar.

Alasan mengapa sistem informasi akuntansi tidak mempunyai pengaruh terhadap laporan keuangan diantaranya adalah kurangnya pemahaman tentang arti penting sistem informasi akuntansi dan pelaporan keuangan. Para pelaku UMKM di Desa Banyuanyar beranggapan bahwa laporan keuangan itu hanya menambah beban pekerjaan mereka dan tidak bisa menghasilkan sesuatu yang secara langsung bermanfaat bagi para pelaku UMKM di Desa Banyuanyar.

Selain itu, menurut pendapat mereka pembuatan laporan keuangan terlalu banyak melalui tahapantahapan prosedur laporan keuangan. Para pelaku UMKM menganggap bahwa sistem informasi akuntansi belum perlu diterapkan pada laporan keuangan mereka, karena meskipun mereka menerapkan sistem informasi akuntansi, SIA tidak mampu memberikan pendapatan yang lebih dan tidak berpengaruh pada proses usaha yang mereka lakukan.

\section{b. Uji Koefisien Determinasi}

Tabel 8. Uji ( $\left.\mathrm{R}^{2}\right)$ Koef. Determinasi

\begin{tabular}{|l|r|r|r|r|r|}
\hline Model & \multicolumn{1}{|c|}{$\mathrm{R}$} & $\mathrm{R}$ Square $\left(\mathrm{R}^{2}\right)$ & & Adj. $\mathrm{R}^{2}$ & Estimasi Std. Error \\
\hline 1 & $.065^{\mathrm{a}}$ & .004 & & -.017 & 2.44131 \\
\hline
\end{tabular}

Sumber: Data Diolah, 2020 
Berdasarkan hasil tabel 8. terlihat bahwa nilai koefisien determinasi sebesar 0.065 dimana analisis hitung $1-0.065=0,935$. Artinya nilai koefisien determinasi sebesar 0.065 atau $6,5 \%$ yang berarti bahwa Sistem Informasi Akuntansi berpengaruh sebesar 6,5\% terhadap Kinerja karyawan dan sisanya $93,5 \%$ dipengaruhi oleh variabel lain diluar penelitian.

\section{Simpulan}

Berdasarkan analisis yang telah dilakukan, dapat disimpulkan bawasanya penerapan sistem informasi akuntansi memiliki pengaruh terhadap efektifitas laporan keuangan, tetapi tidak signifikan. Hal ini terlihat dari nilai t_hitung sebesar 0.449 dengan nilai signifikansi sebesar 0.656. Taraf signifikansi ini menunjukkan jumlah yang lebih besar dari alfa yang ditetapkan yaitu sebesar 0,05 . Saran yang bisa diusulkan diantaranya adalah memberikan pelatihan tentang sistem informasi akuntansi, pelatihan pembuatan laporan keuangan sesuai dengan SAK ETAP, serta penyuluhan tentang arti penting pembuatan laporan keuangan, sekaligus penyuluhan tentang arti penting penerapan sistem informasi akuntansi.

\section{Daftar Pustaka}

Aliya, S., \& Tobari, T. (2019). Pengaruh Pendidikan dan Pelatihan Terhadap Produktivitas Kerja Karyawan Bagian Produksi pada PT. Semen Baturaja (PERSERO) TBK Palembang. JMKSP (Jurnal Manajemen, Kepemimpinan, Dan Supervisi Pendidikan), 4(1), 97. https://doi.org/10.31851/jmksp.v4i1.2480

Anggraeni, Elisabet Yunaeti dan Irviani, Rita. (2017). Pengantar Sistem Informasi. Edisi 1. Yogyakarta: Andi Offset

Ghozali, Imam. (2013). Aplikasi Analisis Multivariat Dengan Program SPSS Edisi 7. Semarang: Badan Penerbit Universitas Diponegoro

Hutahaean, Jeperson. (2014). Konsep sistem informasi edisi 1. Yogyakarta: Deepublish

Kusrini, (2010). Tuntunan Praktis Membangun Sistem Informasi Akuntansi Dengan Visual Basic Dan Microsoft SQL Server. Yogyakarta: Andi Offset

Mahatmayo, Atyanto. (2014). Sistem Informasi Akuntansi:Suatu Pengantar. Yogyakarta: Deepublish

Mulyani dkk. (2018). Sistem Informasi Akuntansi:Aplikasi Di Sektor Publik: Panduan Praktis. Bandung:Unpad press

Pinasti, margani. (2007). Pengaruh Penyelenggaraan Dan Penggunaan Informasi Akuntansi Terhadap Persepsi Pengusaha Kecil Atas Inforasi Akuntansi: Suatu Riset Eksperimen. Jurnal Riset Akuntansi Indonesia, 10 (3), hal.321-331

Sugiyono. (2015). Statistik Untuk Penelitian. Bandung:alfabeta

\section{Copyright Disclaimer}

Copyright for this article is retained by the author(s), with first publication rights granted to the journal. 